\title{
MAXIMUM DIVE DEPTHS OF EIGHT NEW ZEALAND PROCELLARIIFORMES, INCLUDING PTERODROMA SPECIES
}

\author{
by G. A. Taylor
}

\author{
(with four text-figures, one plate and one table)
}

\begin{abstract}
Taylor, G.A. 2008 (31:x): Maximum dive depths of eight New Zealand Procellariiformes, including Pterodroma species. Papers and Proceedings of the Royal Society of Tasmania 142(1): 89-98. https://doi.org/10.26749/rstpp.142.1.89 ISSN 0080-4703. Research \& Devclopment Group, Department of Conservation, PO Box 10420, Wellington, New Zealand. Email: g.taylor@doc.govt.nz
\end{abstract}

\begin{abstract}
Lightweight capillary tube depth gauges were attached to eight petrel species breeding at New Zealand colonies during the period $1998-2008$. This paper presents the first information on the diving ability of Pterodroma petrels. Grey-faced Petrels, Pterodroma macroptera gouldi, recorded maximum dives down to $23 \mathrm{~m}$. Males $(6.3 \pm 6.3 \mathrm{~m} \mathrm{SD})$ dived deeper on average than females $(3.6 \pm 2.5 \mathrm{~m})$ during the incubation period but not significantly so $(\mathrm{P}=0.06)$. Breeding birds dived significantly deeper on average than non-breeders, and breeding males dived significantly deeper on average than non-breeding males. The two small Pterodroma species sampled, Pterodroma pycrofti and Pterodroma nigripennis, only exhibited shallow dives down to $2 \mathrm{~m}$ but sample sizes were small. Sooty Shearwaters, Puffinus griseus, had mean maximum dive depths of $42.7 \pm 23.7 \mathrm{~m}$, with males $(53.0 \pm 17.3 \mathrm{~m})$ diving significantly deeper on average than females $(20.1 \pm 20.4 \mathrm{~m})$ during the incubation period. One male Sooty Shearwater dived to nearly $93 \mathrm{~m}$, the deepest dive so far recorded in the order Procellariiformes. Flesh-footed Shearwaters, Puffinus carneipes, dived to $28 \mathrm{~m}$, with a mean maximum dive depth of $13.6 \pm 7.9 \mathrm{~m}$. Hutton's Shearwaters, Puffinus huttoni, had a mean maximum dive depth of $23.0 \pm 8.5 \mathrm{~m}$ (range 11.1-36.6 m). A single Fluttering Shearwater, Puffinus gavia, recovered with a dive gauge had dived to $29 \mathrm{~m}$. Mean maximum dives made by Common Diving-Petrels, Pelecanoides urinatrix, of 10.9 $\pm 6.1 \mathrm{~m}$ (range 6.9-22.2 m) were shallower than results reported from other sites but may have been biased by gauge failures. Capillary gauges provide the best means we have at present to understand the diving capability of small seabirds. While studies elsewhere have shown these gauges may overestimate diving performance by about $10-15 \%$, other factors identified in this study indicate that sometimes diving performance will be underestimated using this simple technique.
\end{abstract}

Key Words: maximum dive depths, sex-specific behaviour, seabirds, Pterodroma, Puffinus, Pelecanoides, New Zealand.

\section{INTRODUCTION}

Electronic time depth recorders (TDRs) have been used to examine dive profiles of many large and medium-sized seabirds such as King Penguins, Aptenodytes patagonicus J.F. Miller, 1778 (Sato et al. 2002), Little Penguins, Eudyptula minor J.R. Forster, 1781 (Ropert-Coudert et al. 2006) and shags (Wanless et al. 1999). Early model TDRs were relatively heavy ( $40-50 \mathrm{~g}$ ) which limited their usefulness for small seabirds $(<1 \mathrm{~kg})$. In recent years, smaller and lighter TDRs (down to $16 \mathrm{~g}$ ) have been used on seabirds as small as Rhinoceros Auklets, Cerorhinca monocerata (Pallas, 1811), weighing 550-600 g (Watanuki et al. 2006), but these devices are still quite expensive for large-scale deployment. Low-cost and lightweight $(<1 \mathrm{~g})$ plastic capillary tube depth gauges (Burger \& Wilson 1988) have been attached to seabirds since the 1980 s to examine diving performance, especially the maximum depth reached by seabirds. The technique has been used on a wide range of seabird groups, including penguins(Sphenisciformes), gannets, boobies, tropicbirds and cormorants (Pelecaniformes) and alcids (Charadriiformes) (Burger \& Simpson 1986, Scolaro \& Suburo 1991, Adams \& Walter 1993, Le Corre 1997, Casaux et al. 2001).Eighteen species of tube-nosed seabirds (Procellariiformes) have had their maximum dive depths recorded (Prince et al. 1994, Bocher et al. 2000, Brooke 2004); the notable absence in this group includes members of the genus Pterodroma.

Maximum depth gauges (MDGs) consist of short lengths of fine gauge (c. $1 \mathrm{~mm}$ internal diameter) tubing that are attached to foraging seabirds. MDGs allow dive depths to be estimated through compression of a known volume of air inside the tubes, marked with indicator powder. Seawater drawn into the tubes, as a result of air compression as the bird dives, dissolves this powder leaving a boundary mark from which calculation of dive depth can be made.

In 1998, the New Zealand Department of Conservation began trials on an underwater line-setting device as part of a research program to develop techniques to mitigate the impact of seabird bycatch by long-line fisheries. Prior research on White-chinned Petrels, Procellaria aequinoctialis Linnaeus, 1758, (Huin 1994) and albatross (Prince et al. 1994) indicated that some Procellariiformes had much greater diving abilities than previously suspected (Warham 1990). Capable diving species were exposed to a greater risk behind fishing boats as they could pursue sinking baits on hooks deeper into the water column. Seabird species at risk from taking baited hooks in the New Zealand region (Robertson et al. 2004) included several species with unknown diving ability (Brooke 2004). The early part of this study included an assessment of the diving ability of Grey-faced Petrels, Pterodroma macroptera gouldi (Hutton, 1869), and Flesh-footed Shearwaters, Puffinus carneipes Gould, 1844, two common breeding species in northern New Zealand and known to be captured by fishing fleets targeting tuna species (Robertson et al. 2004).

MDGs were attached to Sooty Shearwaters, Puffinus griseus (J.F. Gmelin, 1879), to compare the diving ability of birds nesting in northern New Zealand with those birds breeding at the Snares Islands, $11^{\circ}$ of latitude further south (Weimerskirsch \& Sagar 1998). Over the following 10 years, further seabird species were sampled on an opportunistic basis during other studies (e.g., Miskelly \& Taylor 2004). The five additional species included Common DivingPetrel, Pelecanoides urinatrix (J.F. Gmelin, 1789), Hutton's and Fluttering shearwaters, Puffinus buttoni Matthews, 1912, and P. gavia (J.R. Forster, 1844), Black-winged and 
Pycroft's petrels, Pterodroma nigripennis (Rothschild, 1893) and $P$ pycrofti Falla, 1933.

The aim of this paper is to bring together dive depth data across a range of New Zealand Procellariiformes (four main study species and four other species with smaller sample sizes) to compare diving behaviour and its role in niche separation, at an interspecific and intraspecific level. The partitioning of diving behaviour between sexes and birds of different breeding status is also examined. These types of data are also useful in the ongoing development of fisheries mitigation techniques for several at-risk seabird species and will help inform managers about the risks to diving seabirds from proposed new technologies such as tidal power generation plants.

\section{METHODS}

Fieldwork was carried out at seven different seabird colonies around New Zealand during the period 1998-2008. The main study areas were on Kauwahaia and Ihumoana islands, Bethell's Beach, near Auckland (36 $54^{\prime} S, 174^{\circ} 26^{\prime} \mathrm{E}$ ) (pl. 1) between 5 July 1998 and 29 December 1999. Grey-faced Petrels, Sooty Shearwaters and Flesh-footed Shearwaters breed on Kauwahaia Island and Grey-faced Petrels breed on Ihumoana Island. The Hutton's Shearwater breeding colony in the Kowhai River, Seaward Kaikoura Range ( $\left.42^{\circ} 16^{\prime} \mathrm{S}, 173^{\circ} 36^{\prime} \mathrm{E}\right)$, was visited from 11-20 September 2001. Opportunistic sampling of petrels was carried out at the remaining study sites. Motumahanga Island (Sugarloaf Islands), near New Plymouth $\left(39^{\circ} 03^{\prime} \mathrm{S}, 174^{\circ} 01^{\prime} \mathrm{E}\right)$ was visited from 16-20 November 1998. Flesh-footed Shearwaters and Common Diving-Petrels breed at this site. North Brothers Island, Cook Strait $\left(41^{\circ} 06^{\prime} \mathrm{S}, 174^{\circ} 25^{\prime} \mathrm{E}\right)$ was visited from 25-27 November 1998. Common Diving-Petrels breed at this site. East Island $\left(37^{\circ} 41^{\prime} \mathrm{S}, 178^{\circ} 34^{\prime} \mathrm{E}\right)$ was visited from $19-23$ November 2001 . Fluttering Shearwaters and Black-winged Petrels breed at this site. Cuvier Island $\left(36^{\circ} 25^{\prime} \mathrm{S}, 175^{\circ} 46^{\prime} \mathrm{E}\right)$ was visited from 4-11 February 2008. Pycroft's Petrels now breed at this newly established colony (11 pairs in 2008).

MDGs used in this study were made from lengths of clear flexible PVC plastic tubing $(2.0 \mathrm{~mm}$ external diameter, 0.8 $\mathrm{mm}$ internal diameter) supplied by Ceelon Plastics Ltd, Wellington. Variable lengths of tubing were cut (typically $120 \mathrm{~mm}$ but lengths ranged between $76 \mathrm{~mm}$ and $200 \mathrm{~mm}$ depending on the size of the species). Shorter tubes were used on small species such as Common Diving-Petrels. A thin layer of dry icing sugar was drawn through the tubes after slightly moistening the interior by blowing through the tube. One end of the tube was heated and sealed by squeezing together with pliers. However, during sampling on Common Diving-Petrels in November 1998, I found this sealing technique was not always reliable. This problem was avoided in subsequent deployments during 1998 and 1999 by sealing the closed end of the tube with wax and/ or epoxy resin. Heated wax or epoxy resin was drawn up slightly into the tube which was then heat-sealed to provide a more secure fix. From 1999 onwards, the closed end was dipped and covered in epoxy resin after heat-sealing.

MDGs were attached to the central tail feathers of most species using waterproof adhesive tape (several brands of ducting tape). Species with very short tail feathers (e.g., Common Diving-Petrels, Fluttering and Hutton's shearwaters) had the MDGs attached by tape to the central back feathers. To avoid problems with water being forced

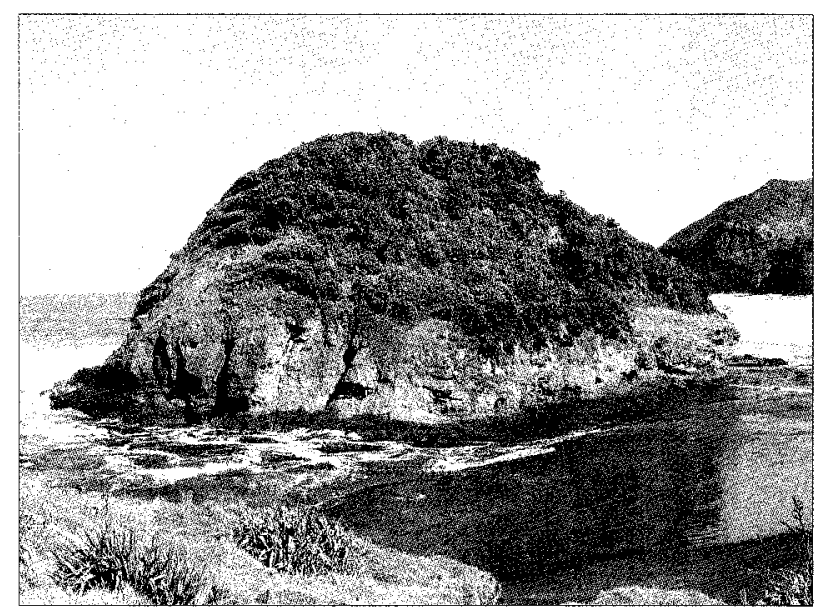

PLATE 1

Kawwahaia Island, Bethell's Beach, New Zealand. This island was the main study site for the work on Grey-faced Petrels, Sooty and Flesh-footed shearwaters in 1998 and 1999. A Sooty Shearwater breeding on this island made the deepest dive $(93 \mathrm{~m})$ so far recorded in any species of Procellariformes.

up the tubes if the birds plunge-dived, the open end of the tube was pointed towards the end of the tail. Attachment generally took only 1-3 minutes per bird with MDGs being attached to birds caught on the ground at night or on birds found incubating eggs or feeding chicks. All the birds used in this study were also fitted with metal bands supplied by the New Zealand National Bird Banding Scheme.

Birds were recaptured on the ground on subsequent nights or located in nesting chambers after they returned from a foraging trip. Upon recovery of each $\mathrm{MDG}$, the total length of the tube was measured from the opening to the heat sealed end or where the wax or epoxy resin started adjacent to the sugar-coated section. The length of clear tubing was then measured to the nearest $0.5 \mathrm{~mm}$ and the sugar-coated portion remaining in the tube was obtained by subtracting the total length of tube from the clear portion lacking sugar. Maximum diving depth was calculated by the equation: $\mathrm{D}=10.08$ ([Ls/Ld]-1) where $\mathrm{D}$ is depth $(\mathrm{m}), 10.08$ is the height $(\mathrm{m})$ of a column of sea water equivalent to 1 atmosphere of pressure, $L s$ is the initial length (mm) of icing sugar and Ld the length (mm) of icing sugar remaining after the foraging trip (Burger \& Wilson 1988).

All of the breeding Grey-faced Petrels, Flesh-footed Shearwaters and Sooty Shearwaters sampled at the Bethell's Beach colonies were sexed by cloacal examination just after laying (data collected 1989-2007). Additionally, every bird sampled in the trials at the Bethell's Beach colonies had their sex validated by DNA tests carried out on blood samples collected between 1996 and 2001 . The sex of birds at other study sites used in this paper was unknown.

\section{Grey-faced Petrels}

MDGs were attached to 199 Grey-faced Petrels on Kauwahaia and Ihumoana islands in 1998. The first batch of MDGs was attached to 48 males and 76 females from 5-13 July 1998 (during the early incubation period). Twenty of these birds (three males and 17 females) were recaptured and released again with a replacement MDG in July or August. Two males and one female from the first batch had a third MDG 
deployment. Another 45 different birds ( 15 males, 30 females) were captured from 20-23 August 1998 (during the hatching period) and released with a second batch of MDGs. Six of these birds (three males and three females) were recaptured in August and released with a replacement MDG. One female from the second batch had a third MDG deployment.

Non-breeding Grey-faced Petrels were separated from breeding birds by a combination of behavioural traits and examination of differences on their bodies. All burrows on the two islands were monitored each season so breeding occupants were identified as banded birds incubating eggs or feeding chicks in each burrow. Non-breeding birds were identified by their behaviour during the species incubation period (calling and roaming activity on the ground at night, displaying to other birds away from burrows, responding to human calls or sleeping on the surface). The weights of non-breeding birds were also lighter than breeders, and cloacal examination around the time of laying separated non-breeding females from those that had laid eggs. Brood patch status was checked for all birds during the incubation period. The brood patches of breeding birds were bare with abundant blood vessels on the surface but those of nonbreeders were downy or lacking obvious vascular tissue.

\section{Flesh-footed Shearwaters}

MDGs were attached to 12 non-breeding Flesh-footed Shearwaters (sex unknown) on Motumahanga Island from 16-18 November 1998 during the pre-laying period. MDGs were attached to 20 incubating adults (ten males and ten females) on Kauwahaia Island from 1-11 December 1998. Seventeen breeding birds (eight males and nine females) had MDGs attached from 5-11 December 1999; five of these males and two of the females had also been used in the 1998 deployment.

\section{Sooty Shearwaters}

MDGs were attached to 45 incubating Sooty Shearwaters (29 males and 16 females) on Kauwahaia Island from 1-11 December 1998. Thirty incubating Sooty Shearwaters were sampled on the same island from 5-11 December 1999. These included six males and seven females not used in 1998. However, 16 males and one female had MDGs attached previously in 1998.

\section{Hutton's Shearwaters}

MDGswere attached to 29 Hutton's Shearwaters from 11-20 September 2001 during the pre-laying courtship period. At this stage of the breeding season, heavy snow covered the burrow entrances preventing access to nest chambers resulting in birds only visiting the colony overnight before returning to sea.

\section{Other petrel species}

MDGs were attached to 26 Common Diving-Petrels on Motumahanga Island from 16-18 November 1998 and on two birds on North Brothers Island from 25-27 November 1998. As most birds were captured on the ground soon after landing, the sample represents an unknown proportion of breeding and non-breeding birds.

Six Fluttering Shearwaters of unknown status were captured on East Island on 19 November 2001 and had
MDGs attached. Birds at this stage of the season were feeding young chicks.

MDGs were attached to 14 Black-winged Petrels on East Island on 19 November 2001 during the pre-laying courtship period. Ten Pycroft's Petrels on Cuvier Island had MDGs attached on 4-5 February 2008. Some were adults feeding chicks and the remaining birds were non-breeders.

\section{Statistics}

The effect of MDG deployment duration on comparisons made between sexes and birds of different breeding status for Grey-faced Petrels, and between sexes of Flesh-footed and Sooty shearwaters, was assessed using an ANCOVA model on JMP 5.1 (SAS Institute Inc), with the days to recovery being the covariate. All data were log transformed prior to running this model. Data normality was assessed using Kolmogorov-Smirnov tests. Log transformations were needed to normalise the skewed Grey-faced Petrel dataset. Differences in the means of normally distributed data were assessed using Student $\mathrm{t}$-tests for differences between sexes and breeding status. Correlations between dive depths and days until MDG recovery were analysed using Pearson correlation coefficients. Maximum dive depths are given as means \pm SD. Statistical tests and descriptive statistics were run on the program SigmaStat ver. 3.0., with the exception of the ANCOVA model.

\section{RESULTS}

Mean $( \pm S D)$, median and range of maximum dive depths for the eight species studied in this project are summarised in table 1. This table also includes the mean $( \pm S D$ ) and range of $M D G$ deployment duration (the number of days between placement of MDG on the birds and their subsequent recapture) for each species. The ANCOVA models found no effect of deployment duration on the differences obtained between sexes or breeding status of birds in the Grey-faced Petrel, Flesh-footed Shearwater or Sooty Shearwater datasets.

\section{Grey-faced Petrel}

Only 102 (51\%) of the Grey-faced Petrels deployed with MDGs were recaptured again in July or August 1998. Thirtyseven (36\%) of these birds had MDGs that malfunctioned or were lost. Eighteen had puncture holes in the tubes or the heat seals had broken, as a result of the birds attempting to remove the tubes. Twelve birds returned with no MDGs because they had lost tail feathers or the tubes detached from the tape. A further seven birds were recovered with a dirt plug blocking the end of the tube and the icing sugar still intact. No dive depth data were recorded for these 37 individuals. MDGs with readable sugar traces were recovered from 65 birds (64\%), including 10 birds that were sampled twice and one bird that was sampled three times. To avoid pseudo-replication issues from non-independence of samples, only the maximum dive depth recorded for each individual is used in the analysis for this species.

The mean maximum diving depth reached by sampled Grey-faced Petrels $(\mathrm{n}=53$ ) was $4.7 \pm 4.7 \mathrm{~m}$ (range 0.7$23.6 \mathrm{~m}$ ) (table 1). Maximum dives by both sexes did not produce normal distributions (K-S test 0.22 for females, 0.27 for males, $\mathrm{P}<0.0001$ ) (fig. 1 ) and a $\log$ transformation was used to normalise these data before conducting the 
Student t-test analysis. The mean maximum dive depths of males $(6.3 \pm 6.3 \mathrm{~m}, \mathrm{n}=22)$ and females $(3.6 \pm 2.5 \mathrm{~m}$, $\mathrm{n}=31)$ were not significantly different $(\mathrm{t}=1.92, \mathrm{df}=51$, $\mathrm{P}=0.06$ ) (fig. 1).

Breeding Grey-faced Petrels $(n=25)$ dived significantly deeper than non-breeding birds $(\mathrm{n}=28)(6.6 \pm 5.8 \mathrm{~m}$ versus $3.0 \pm 2.3 \mathrm{~m} ; \mathrm{t}=3.6, \mathrm{df}=51, \mathrm{P}<0.01)$ Breeding males ( $\mathrm{n}$ $=17$ ) dived significantly deeper than non-breeding males ( $\mathrm{n}$ = 5) $(7.5 \pm 6.7 \mathrm{~m}$ versus $2.2 \pm 0.9 \mathrm{~m} ; \mathrm{t}=2.31, \mathrm{df}=20, \mathrm{P}$ $=0.03)$. However, the dives of breeding females $(4.6 \pm 2.4$ $\mathrm{m}, \mathrm{n}=8$ ) were not significantly deeper than those of nonbreeding females $(3.2 \pm 2.5 \mathrm{~m}, \mathrm{n}=23)(\mathrm{t}=1.85, \mathrm{df}=29, \mathrm{P}$ $=0.07$ ). There was a highly significant relationship between MDG deployment duration and diving depth $(\mathrm{r}=0.52 \mathrm{df}$ $=51, \mathrm{P}<0.01)$. However, apart from two MDGs that gave much deeper readings after the longer deployment period, the remaining MDGs had a similar distribution of dive depths when deployed between 1 and 10 days compared with those deployed for 38-54 days (fig. 2).

\section{Flesh-footed Shearwater}

Five $(42 \%)$ of the Flesh-footed Shearwaters sampled on Motumahanga Island were recaptured with readable MDGs. Eighteen $(90 \%)$ of the Flesh-footed Shearwaters sampled on Kauwahaia Island in 1998 were recaptured between 6 December 1998 and 2 January 1999. Four of these birds were recaptured twice after a subsequent set of MDGs was deployed. Ten (59\%) of the birds sampled in 1999 on Kauwahaia Island were recaptured from 10-29 December 1999. Readable MDGs were present on 22 birds (15 in 1998 and seven in 1999). These included four individuals that had two maximum dive depth samples collected. To avoid pseudo-replication issues from non-independence of samples, only the maximum dive depth recorded for each individual $(\mathrm{n}=18)$ recorded over the two sampling years on Kauwahaia Island is used in the analysis for this species.

The mean maximum dive depth for all sites and years combined was $13.6 \pm 7.9 \mathrm{~m}$ (range $0.8-28.7 \mathrm{~m}, \mathrm{n}=23$ ) (table 1). The mean maximum dive depth recorded from the incubating birds at Kauwahaia Island was $16.8 \pm 5.5$ $\mathrm{m}$ (range $8.2-28.7 \mathrm{~m}, \mathrm{n}=18$ ). There was no significant difference $(t=1.94, \mathrm{~d} f=16, \mathrm{P}=0.07)$ in the dives of males from Kauwahaia Island $(18.7 \pm 5.2 \mathrm{~m}, \mathrm{n}=11)$ compared with females $(13.9 \pm 5.1 \mathrm{~m}, \mathrm{n}=7)$. There was a significant positive relationship between the duration that MDGs were on birds and maximum diving depth $(r=0.45, \mathrm{df}=$ $21, P=0.03$ ), (fig. 3). However, there was no relationship between deployment duration and maximum dive depths when only the incubating birds at Kauwahaia Island were tested $(\mathrm{r}=-0.16, \mathrm{df}=16, \mathrm{P}=0.52)$.

\section{Sooty Shearwater}

Forty-four (59\%) of the Sooty Shearwaters deployed with MDGs in 1998 and 1999 were subsequently recaptured within 30 days. Ten (22\%) of the birds sampled in the 1998 season and nine (30\%) sampled in the 1999 season were recaptured with readable MDGs. These included three individuals that had two maximum dive depth samples collected. To avoid pseudo-replication issues from non-independence of samples, only the maximum dive depth recorded for each individual $(n=16)$ is used in the analysis for this species.

The mean maximum dive depth for the sampled Sooty Shearwaters (both sexes) for 1998 and 1999 combined was $42.7 \pm 23.7 \mathrm{~m}$ (range 1.2-92.9 m, n=16) (table 1). Males $(53.0 \pm 17.3 \mathrm{~m}, \mathrm{n}=11)$ dived significantly deeper than females $(20.1 \pm 20.4 \mathrm{~m}, \mathrm{n}=5)(\mathrm{t}=3.33, \mathrm{df}=14, \mathrm{P}<0.01)$. Dive depths increased significantly with the duration that MDGs were deployed on birds ( $r=0.54, P=0.03, n=16$ ), (fig. 4).

One male Sooty Shearwater (Z-20733) on Kauwahaia Island produced a maximum dive of nearly $65 \mathrm{~m}$ after only two days at sea. However, this dive is not included in the results above as this same bird went on to register a dive of almost $93 \mathrm{~m}$ on the next MDG deployment, the deepest dive so far recorded for this species.

\section{Hutton's Shearwaters}

Fifteen $(52 \%)$ of the Hutton's Shearwaters were recaptured at the breeding colony up to five days after MDG deployment. Thirteen $(45 \%)$ of these birds had intact, readable MDGs and the other two had lost their tubes but retained the tape on the feathers. Hutton's Shearwaters had a mean maximum dive depth of $23.0 \pm 8.5 \mathrm{~m}$ (range $11.1-36.6 \mathrm{~m}, \mathrm{n}=13$ ) (table 1).

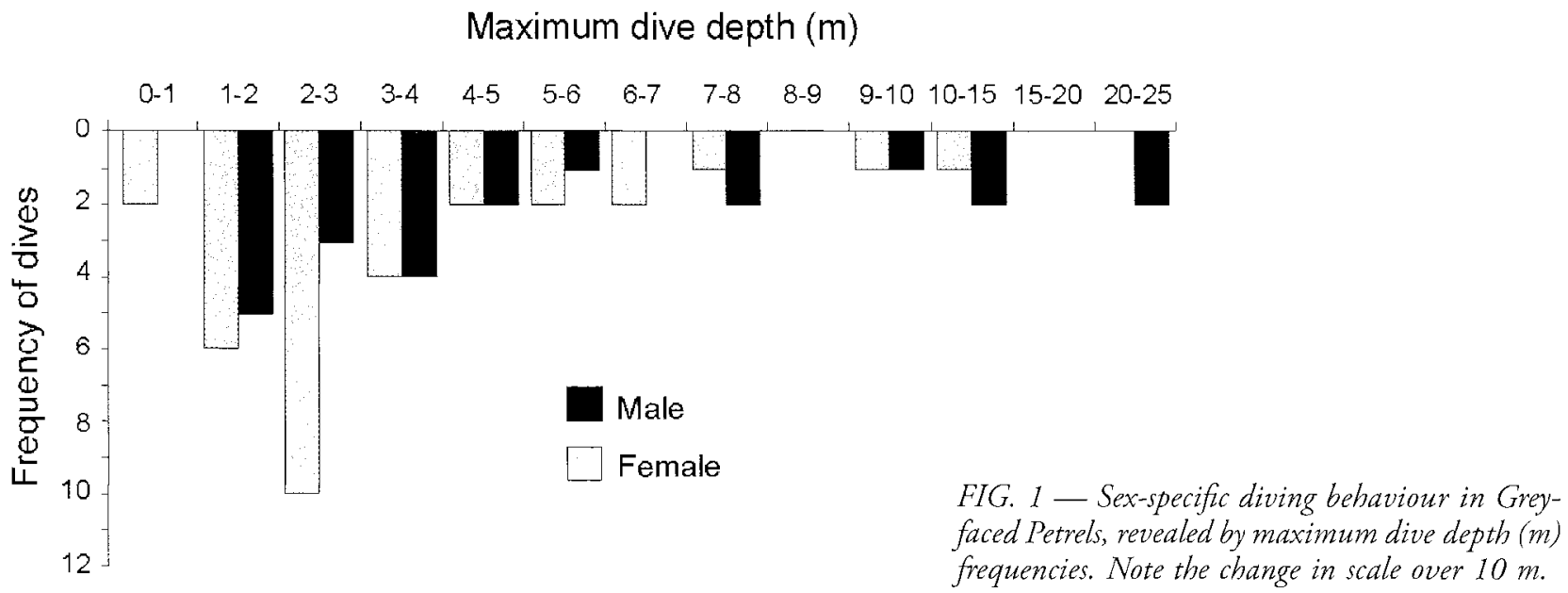




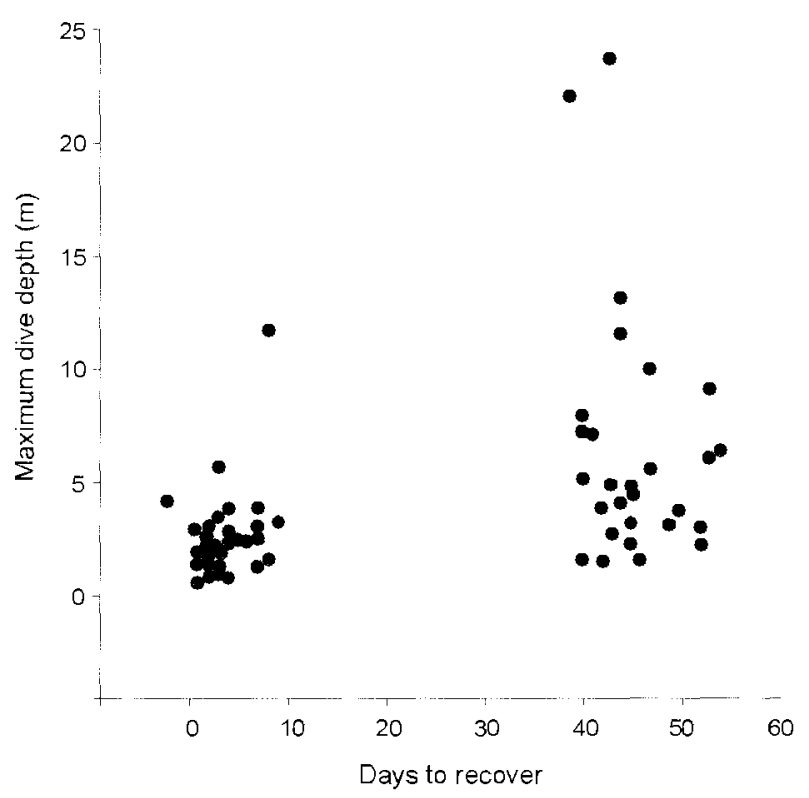

FIG. 2 - Duration of MDG deployment versus maximum dive depth (m) for Grey-faced Petrels.

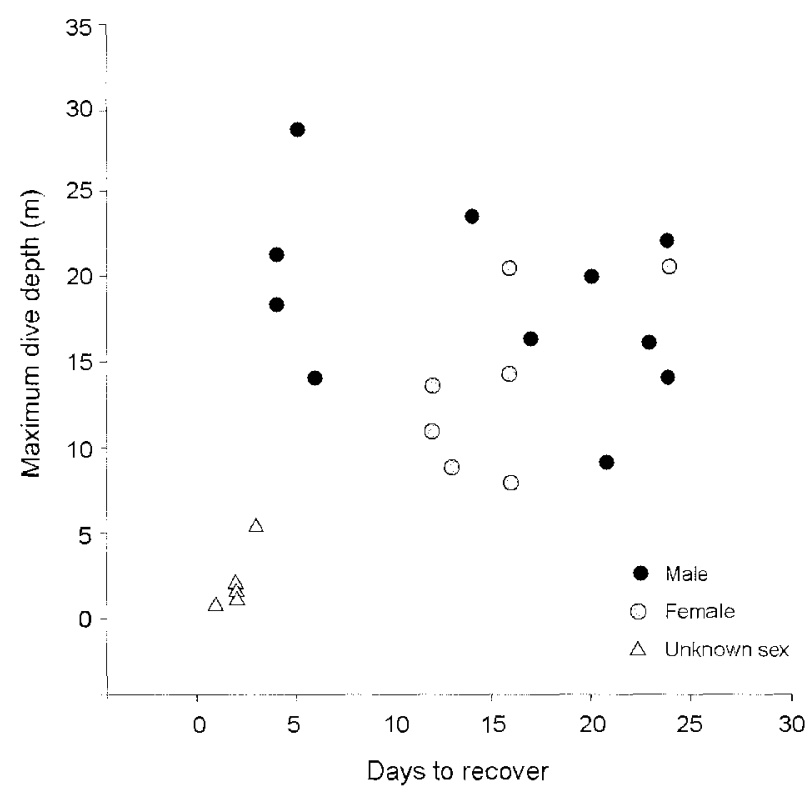

FIG. 3 - Duration of MDG deployment versus maximum dive depth (m) for Flesh-footed Shearwaters.

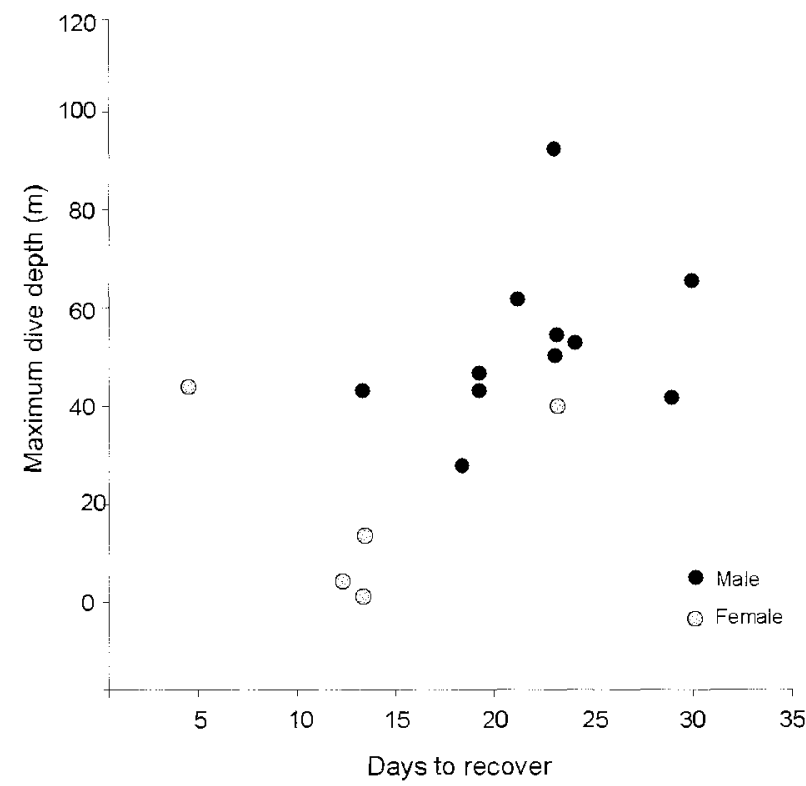

FIG. 4 - Duration of MDG deployment versus maximum dive depth (m) for Sooty Shearwaters.

TABLE 1

Summary statistics of the maximum dive depths and trip duration for eight species of petrel

\begin{tabular}{|c|c|c|c|c|c|c|c|c|}
\hline \multirow[t]{2}{*}{ Species } & \multicolumn{5}{|c|}{ Maximum Dive Depths (m) } & \multicolumn{3}{|c|}{ Trip Duration (days) } \\
\hline & $\mathrm{n}$ & Median & Mean & SD & Range & Mean & $\mathrm{SD}$ & Range \\
\hline Grey-faced Petrel & 53 & 3.1 & 4.7 & 4.7 & $0.7-23.6$ & 25.9 & 21.0 & $1-54$ \\
\hline Black-winged Petrel & 4 & 1.6 & 1.6 & 0.3 & $1.3-1.9$ & 2.8 & 0.5 & $2-3$ \\
\hline Pycroft's Petrel & 3 & 1.1 & 1.1 & 0.5 & $0.6-1.6$ & 2.3 & 0.6 & $2-3$ \\
\hline Sooty Shearwarer & 16 & 44.3 & 42.7 & 23.7 & $1.2-92.9$ & 19.3 & 6.9 & $4-30$ \\
\hline Flesh-footed Shearwater & 23 & 14.1 & 13.6 & 7.9 & $0.8-28.7$ & 12.2 & 8.2 & $1-24$ \\
\hline Hutton's Shearwater & 13 & 20.3 & 23.0 & 8.5 & $11.1-36.6$ & 2.3 & 1.1 & $1-5$ \\
\hline Fluttering Shearwater & 1 & 29.4 & - & - & 29.4 & 2 & - & 2 \\
\hline Common Diving-Petrel & 6 & 7.8 & 10.9 & 6.1 & $6.9-22.2$ & 1.5 & 0.5 & $1-2$ \\
\hline
\end{tabular}




\section{Other petrel species}

Eighteen (64\%) of the 28 Common Diving-Petrels sampled in 1998 were recaptured one or two nights after MDG deployment. There was a high failure rate for MDGs deployed on this species. Nine $(50 \%)$ of the MDGs recovered had broken heat seals and no sugar inside the tubes, and three birds had lost their MDG but retained the tape on their feathers. Only six of the birds recaptured (33\%) had readable MDGs. Mean maximum dive depth of Common DivingPetrels sampled at Motumahanga Island $(n=5)$ and North Brothers Island $(n=1)$ was $10.9 \pm 6.1 \mathrm{~m}$ (range 6.9-22.2 $\mathrm{m}, \mathrm{n}=6)($ table 1$)$.

Only one (17\%) of the Fluttering Shearwaters deployed with a MDG on East Island was recaptured. This bird had dived $29 \mathrm{~m}$ in the two days it was out at sea.

Four $(29 \%)$ of the Black-winged Petrels were recaptured on East Island 2-3 nights after deployment; all with intact MDGs. These birds had a mean maximum dive depth of 1.6 $\pm 0.6 \mathrm{~m}$ (range $1.3-1.9 \mathrm{~m} \mathrm{n}=4$ ) (table 1 ). Three $(25 \%)$ of the Pycroft's Petrels with MDGs attached were recaptured at the Cuvier Island colony prior to departure from the island on 12 February; all three had readable MDGs. These birds had a mean maximum dive depth of $1.1 \pm 0.5 \mathrm{~m}$ (range $0.6-1.6, \mathrm{n}=3)($ table 1$)$.

\section{DISCUSSION}

\section{Interspecific comparisons}

The maximum dive depths of Grey-faced Petrels, Flesh-footed, Hutton's and Sooty shearwaters (the four species with more than 10 readable MDGs recovered in this study) suggests niche separation with each species using a different zone of water near the ocean surface. Grey-faced Petrels exploit a diverse range of squid species and lesser amounts of fish and crustaceans (Imber 1973). The findings in this study indicate that most of these prey items are gathered near the ocean surface (in the top $5 \mathrm{~m}$ of the water column) but some prey could be taken at depths down to $23 \mathrm{~m}$. Shearwaters feed mainly on small fish or crustaceans (especially krill and amphipods) caught during diurnal feeding sessions (Marchant \& Higgins 1990 , Warham 1990, Cruz et al. 2001). Flesh-footed Shearwaters feed mainly on small fish (G. Taylor unpubl. data). This species dived deeper on average than Grey-faced Petrels although their overall depth range was similar. Measurements obtained from MDGs a few days after deployment showed that most dives were less than $5 \mathrm{~m}$ deep. However, Fleshfooted Shearwaters foraging during their partner's incubation shift of around 10 days (G. Taylor unpubl. data) routinely dive between $10-30 \mathrm{~m}$. Hutton's Shearwaters feed mainly on small fish and crustaceans (especially krill) (West \& Imber 1985 ). This species is an even more proficient diver than the two previous species and regularly dives between $10-35 \mathrm{~m}$, even during short foraging trips (1-2 days) away from the colony. Sooty Shearwaters feed mainly on small crustaceans (krill and amphipods) but also take squid and fish (Cruz et al. 2001). Sooty Shearwaters are the most capable diving species of the four larger petrels examined in this study and short trips away from the colony ( $1-5$ days) regularly resulted in maximum dive depths of $40-60 \mathrm{~m}$ and some birds may dive as deep at $93 \mathrm{~m}$.

Brandhorst et al. (1971) (cited by Scolaro \& Suburo 1991) indicated that anchovies, Engraulis anchoita Hubbs
\& Marini, 1935, around South America formed compact fish shoals at depths greater than $35 \mathrm{~m}$ during the day (sometimes down to $75-100 \mathrm{~m}$ ), while at night these fish dispersed thinly 3-20 m below the sea surface. If the small fish (and other prey species) sought by shearwaters in New Zealand behave in a similar way, then this might explain the deep pursuit diving by shearwaters feeding by day, whereas Grey-faced Petrels which feed mainly at night (Imber 1973) could catch these fish stocks near the surface with shallower dives.

The results of this study suggest that petrels of the genus Pterodroma are able to exploit deeper depths in the water column than was previously thought. For example Warham (1990) considered Pterodroma species to be mainly surface feeders and Imber (1973) stated that Grey-faced Petrels would probably capture their prey items within $1 \mathrm{~m}$ of the sea surface, based on diet samples regurgitated from chicks. However, the measurements obtained from this study show that Grey-faced, Pycroft's and Black-winged petrels routinely dive between $0.5 \mathrm{~m}$ and $2 \mathrm{~m}$ below the sea surface on foraging trips, and the larger Grey-faced Petrel often dives between $2-10 \mathrm{~m}$, and a few individuals descend as deep as $23 \mathrm{~m}$. Compared with the shearwaters in this study, the majority of Pterodroma species sampled made relatively shallow dives (less than $10 \mathrm{~m}$ ) which is similar to the diving behaviour exhibited by Bulwer's Petrel, Bulweria bulwerii (Jardine \& Selby, 1828), (maximum depth 5.3 m) (Mougin \& Mougin 2000), Blue Petrels, Halobaena caerulea (J.F. Gmelin, 1789), (maximum depth $6.2 \mathrm{~m}$ ) and Slender-billed Prions, Pachyptila belcheri (Matthews, 1912), (maximum depth 7.5 m) (Chastel \& Bried 1996).

Brown et al. (1978) considered that shearwaters might be able to dive down to $5 \mathrm{~m}$. Anecdotal observations by Wood (1993) and Oka (1994) of Flesh-footed Shearwater and Skira (1979) of Short-tailed Shearwater, Puffinus tenuirostris (Temminck, 1835), foraging behaviour indicated these species had a diving ability of at least $13 \mathrm{~m}$ and 20 $\mathrm{m}$ respectively. The diving skills of shearwaters has become much better known in recent years (Weimerskirch \& Sagar 1996, Burger 2001) and some species are now reported to dive as deep as $71 \mathrm{~m}$ (Weimerskirch \& Cherel 1998). This study has shown that Flesh-footed Shearwaters are more proficient divers than previously thought and that the species regularly dives to $10-20 \mathrm{~m}$ (perhaps as deep as $30 \mathrm{~m}$ ). Hutton's and Fluttering shearwaters appear to be capable of routinely diving to $30-35 \mathrm{~m}$.

The diving ability of Sooty Shearwaters during the chickrearing period was examined using MDGs at the Snares Islands in February and March 1995 (Weimerskirch \& Sagar 1996). Their study birds averaged maximum dives of 38.7 $\mathrm{m}$, with dives ranging between $2-67 \mathrm{~m}$. The exceptional diving ability of Sooty Shearwaters was confirmed in the current study in which mean maximum dives $(42.7 \mathrm{~m}$ and $38.7 \mathrm{~m}$ respectively) were very similar for birds breeding at two localities separated by $11^{\circ}$ of latitude (one colony breeding in temperate seas, the other in cool sub-Antarctic seas). The maximum dive recorded at The Snares and Kauwahaia Islands was $67 \mathrm{~m}$ and $93 \mathrm{~m}$ respectively, the latter being the deepest dive recorded for any Procellariiformes species to date.

The maximum dive depths observed in the small sample measured from Common Diving-Petrels in this study (6.9-22.2 $\mathrm{m}, \mathrm{n}=6$ ) were shallower than those reported by Bocher et al. (2000) for the same species gathered using MDGs at the Kerguelen Islands (7.9-64.1 m, n=347). They 
were also shallower than those reported by Prince \& Jones (1992) using MDGs with South Georgian Diving-Petrels, Pelecanoides georgicus Murphy \& Harper, 1916, at South Georgia (17-48 m, n=6), and Zavalaga \& Jahncke (1997) using MDGs with Peruvian Diving-Petrels, Pelecanoides garnotii Lesson, 1828, in Peru (10-83 m, $\mathrm{n}=22)$. Diving petrels have a remarkable diving ability for their size, but dive depths may be dependent on local food sources and also the depth of the sea floor near the colonies, especially as the species stays quite close to the colonies during chick-rearing (when both parents feed the chick each night) (Miskelly \& Taylor 2004). Some deeper dives may have been missed in the current study however because of the high MDG failure rate. The heat seals on the MDGs used with this species were not secured with epoxy resin. Further studies are clearly required on this species in the New Zealand region.

\section{Sex-specific behaviour}

Sex-specific diving behaviour in monomorphic seabirds has been noted previously in several seabird groups (Lewis et al. 2002). Using activity loggers, Lewis et al. (2002) found that female Northern Gannets, Morus bassanus (Linnaeus, 1758), made longer and deeper dives than males. Similarly, a study using MDGs on Antarctic Shags, Phalacrocorax bransfieldensis Murphy, 1936, recorded females diving significantly deeper than males and females achieved the maximum dive depth for this species of $112.6 \mathrm{~m}$ (Casaux et al. 2001). Studies on inter-sexual differences in diving behaviour are limited for Procellariiformes. Mougin \& Mougin (2000) failed to detect sex-specific differences in the diving ability of Bulwer's Petrels. However, Peck \& Congdon (2006) found that male Wedge-tailed Shearwaters, Puffinus pacifucus (J.F. Gmelin, 1789), dived significantly deeper on average than females. The findings of this study are similar to those of Peck \& Congdon (2006) with male Sooty Shearwaters diving significantly deeper than females during the breeding season. The males of both Grey-faced Petrels and Flesh-footed Shearwaters also dived deeper on average than females but not significantly so. Males in most Procellariiformes are marginally larger than females (Warham 1990) but the difference doesn't seem enough to give a significant advantage during foraging. Peck and Congdon (2006) concluded that inter-sexual competition at the foraging grounds was the most likely explanation for these diving differences.

\section{Effects of breeding status on diving behaviour}

The effects of breeding status on diving behaviour have been studied in cormorants and penguins (Green et al. 2005, Grémillet et al. 2005). However, this study is, to my knowledge, the first to report differences in diving performance based on breeding status in Procellariiformes. Breeding Grey-faced Petrels (breeding males and for both sexes combined) dived deeper than their non-breeding counterparts. A likely explanation for this phenomenon is that breeding birds may need to obtain different prey items (higher dietary quality or more abundant prey) to restore fat reserves quickly while at sea during their partner's incubation shift. Grey-faced Petrel adults lose over $20 \%$ of their body weight during long incubation shifts. For males in particular, who undertake two long incubation shifts of 2-3 weeks each over a two-month period (Imber 1976), rapid recovery of body condition is essential for breeding success (Brooke
2004). Conversely, non-breeding Grey-faced Petrels arrive at the colonies typically $100-200 \mathrm{~g}$ lighter than birds starting an incubation shift ( $450-600 \mathrm{~g}$ versus $630-800 \mathrm{~g}$ for breeders) (Imber 1976, G. Taylor unpubl. data) and could thus afford to pursue less abundant or lower quality prey near the ocean surface compared with breeding birds. Another possibility is that Grey-faced Petrel breeders, though similar in body morphometrics to non-breeders (G. Taylor unpubl. data) have a much larger body mass due to rapid fat storage between incubation shifts. This may enable these birds to retain more body oxygen and insulate them against thermal loss which could enhance their diving performance.

\section{Effect of trip duration}

The results of this study and others (Wanless et al. 1991) suggests that duration of MDG deployment can have a strong influence upon the results. Although maximum dive depths showed a positive increase with trip duration in this study, this was to be expected as the longer MDGs are deployed on birds, the more likely it is that deeper than average dives will be detected. In this study, an ANCOVA model was run to assess whether days to recovery of MDGs influenced the results of the sex and breeding status analysis. No covariate effect was detected.

Grey-faced Petrels proved to be a difficult species to sample diving behaviour. First, non-breeding birds only visit the colony for a few consecutive nights then spend long intervals back at sea (often greater than one week). The lengthy incubation shifts (13-21 days) (Imber 1976, Johnston \& Davis 1990) and foraging spells (1-14 days) (G. Taylor unpubl. data) of breeding Grey-faced Petrels made it impractical to retrieve all MDGs after a single short foraging trip as recommended by Wanless et al. (1991) and Burger (2001). MDGs from breeding birds were mostly retrieved between 38 and 54 days after initial deployment (fig. 2, table 1). Males captured in burrows sitting on an egg in early July would only have spent one spell of 14-21 days at sea between early July and mid- to late August (Johnston \& Davis 1990). The deepest maximum dive depths recorded in the Grey-faced Petrel trial came from MDGs retrieved after this lengthy deployment.

MDG recoveries from Flesh-footed and Sooty shearwaters were similarly affected by the length of incubation shifts and time needed to ensure an incubating bird had finished its shift, gone to sea and returned again to the colony. With the other species sampled in this study, the short duration of the field trips to the breeding colonies limited the opportunities to recover all of the MDGs deployed. MDGs were mostly recovered from birds 1-5 nights after deployment and birds away on longer trips were missed. If birds away on longer foraging trips dive deeper than those visiting the colony after several days, then the dive depths recorded in this study may underestimate the diving ability for some of these species.

\section{Implications of diving behaviour for fisheries interactions}

Flesh-footed Shearwaters and Grey-faced Petrels are incidentally killed as bycatch by commercial fisheries in New Zealand, including on pelagic and demersal longlines (Robertson et al. 2004). The diving ability of these two common New Zealand breeding species has not been studied previously using MDGs. This study suggests that when 
longlines are within $20-30 \mathrm{~m}$ of the surface, these seabird species can be at risk of capture. Longlines occur at such depths during setting and hauling, and are less frequently set to fish at such depths. Cherel et al. (1996) have shown that seabird species that are capable divers are able to recover the baited hooks on the sinking branch lines and return them to the surface where other larger and more aggressive species, e.g., Wandering Albatross, Diomedea exulans Linnaeus, 1758 , have a chance to steal the bait and risk getting hooked. Setting longlines at night is now a preferred mitigation solution. This would give some protection to Flesh-footed Shearwaters, which forage by day (Marchant \& Higgins 1990); however, such action may fail to protect the nocturnally active Greyfaced Petrel (Imber 1973) and other night-feeding petrels.

\section{How reliable are MDGs?}

The basic assumption with using MDGs is that they provide an accurate assessment of the maximum depth reached by individual birds during foraging trips at sea. Burger \& Wilson (1988) pointed out some potential sources of error when using capillary gauges including overestimating diving ability by behaviour such as plunge diving or repeated diving to maximum depths. They also considered that condensation or water retention inside tubes can also cause problems. The risk of overestimating dive depths by birds plunge diving was eliminated by pointing the open end of tubes towards the tail. Any faulty MDGs that retained water within the tubes were discarded in this study. Zavalaga \& Jahncke (1997) tested the validity of results from MDGs by lowering nine MDGs from a research vessel into the sea between depths of $10-150 \mathrm{~m}$. They found that MDG' overestimated real depths by an average of $13.2 \%(2.2-35 \%)$, with shallower depths $(<70 \mathrm{~m})$ being recorded more precisely $(<8 \%$ error) than MDGs deployed to deeper depths ( $>70 \mathrm{~m})$. No explanation was offered by these authors as to why MDGs overestimated real depths. However, in the current study, only one dive was measured beyond $70 \mathrm{~m}$ so the MDG readings should be accurate within $10 \%$.

Soil jammed into the open end of the tube was a new problem encountered in this study, particularly with data collected from breeding birds occupying clay soil burrows. As the burrow chambers tend to be small, the tail is often pressed into the sides of the nest chamber and soil was sometimes pushed into the first $5 \mathrm{~mm}$ of the open end of the tube. This issue is likely to be a significant variable when using MDGs as a method for studying diving behaviour in burrowing seabirds that nest in clay soils. If the dirt in the tube prevented seawater from entering and dissolving the sugar, some of the initial dives may possibly not have been registered by the MDG until the soil was dislodged. The presence of tiny grit particles within the tubes suggests this may have been a common occurrence with the breeding birds on Kauwahaia and Ihumoana islands, and is likely to result in an underestimate of diving performance if some deeper dives were missed. For example, a Grey-faced Petrel recovered 40 days after release still had soil blocking the end of the tube and the sugar was undissolved within the tube. For species that dive infrequently or only dive to shallow depths, water pressure may not be sufficient to dissolve or dislodge these dirt blockages. However, the dirt is more likely to be pushed up the tube, or gradually dissolved when exposed to greater water pressure, longer dive durations or increased frequency of immersion. These latter scenarios are more likely to occur with species that dive to deeper depths.

The sources of error noted above indicate that MDGs will provide only an estimation of diving ability in seabirds. Very small but expensive TDRs (3-6 g) are now becoming available for seabird research. For example, $6 \mathrm{~g}$ Lotek geolocation loggers with built-in pressure sensors were used on Sooty Shearwaters $(n=11)$ and these confirmed that this species is able to reach a depth of at least $68 \mathrm{~m}$ (Shaffer et al. 2006), similar to the typical diving range recorded for this species in two studies using MDGs (see above). However, the lightweight capillary tubes used in this study still provide an inexpensive method to study the diving ability of many small and tiny seabird species weighing less than $500 \mathrm{~g}$.

\section{ACKNOWLEDGEMENTS}

The work on the colonies at Bethell's Beach would not have been possible without the generous support and permission of the Lusk and Woodward families. Thanks also to Craig Millar (Auckland University), David Lambert, Amy Roeder and Linda McDonald (Massey University) who helped collect blood samples and/or did DNA sexing for some of the Greyfaced Petrels, Sooty and Flesh-footed shearwaters used in this study. Colleagues from the Department of Conservation and volunteers assisted with the capture and attachment of capillary depth gauges at various sites over the past 10 years. Special thanks to Rex Williams, Bryan Williams, Paul Gasson, Helen Jonas and Andy Bassett. Peter Moore, Leigh Bull, and Johanna Pierre provided some very helpful comments on an earlier draft. Special thanks to Matt Rayner for his thorough review of the first draft and assistance with the ANCOVA analyses. Chris Edkins (DOC science publishing) drew the figures. The final manuscript was improved by comments from Craig White and Roger Seymour.

\section{REFERENCES}

Adams, N.J. \& Walter, C.B. 1993: Maximum diving depths of Cape Gannets. Condor 95: 734-736.

Bocher, P., Labidoire, B. \& Cherel, Y. 2000: Maximum dive depths of Common Diving-Petrels (Pelecanoides urinatrix) during the annual cycle at Mayes Island, Kerguelen. Journal of Zoology, London 251: 517-524.

Brooke, M. 2004: Albatrosses and Petrels Across the World. Oxford University Press, Oxford: 499 pp.

Brown, R.G.B., Bourne, W.R.P. \& Wahl, T.R. 1978: Diving by shearwaters. Condor 80: 123-125.

Burger, A.E. 2001: Diving depths of shearwaters. Auk 118(3): $755-759$

Burger, A.E. \& Simpson, M. 1986: Diving depths of Atlantic Puffins and Common Murres. Auk 103: 828-830.

Burger, A.E. \& Wilson, R.P. 1988: Capillary-tube depth gauges for diving animals: an assessment of their accuracy and applicability. Journal of Field Ornithology 59(4): 345-354.

Casaux, R., Favero, M., Silva, P. \& Baroni, A. 2001: Sex differences in diving depths and diet of Antarctic Shags at the South Shetland 1slands. Journal of Field Ornithology 72(1): 22-29.

Chastel, O. \& Bried, J. 1996: Diving ability of Blue Petrels and Thin-billed Prions. Condor 98: 627-629.

Cherel, Y., Weimerskirch, H. \& Duhamel, G. 1996: Interactions between longline vessels and seabirds in Kerguelen waters 
and a method to reduce seabird mortality. Biological Conservation 75: 63-70

Cruz, J.B., Lalas, C., Jillett, J.B., Kitson, J.C., Lyver, P.O'B., Imber, M., Newman, J.E. \& Moller, H. 2001: Prey spectrum of breeding sooty shearwaters (Puffinus griseus) in New Zealand. New Zealand Journal of Marine and Freshwater Research 35: 817-829.

Green, J.A., Boyd, I.L., Woakes, A.J., Warren, N.L. \& Butler, P.J. 2005: Behavioural flexibility during year-round foraging in Macaroni Penguins. Marine Ecology Progress Series 296: 183-196.

Grémillet, D., Kuntz, G., Woakes, A.J., Gilbert, C., Robin, J.-P., Le Maho, Y. \& Butler, P.J. 2005: Year-round recordings of behavioural and physiological parameters reveal the survival strategy of a poorly insulated diving endotherm during the Arctic winter. Joumal of Experimental Biology 208: 4231-4241.

Huin, N. 1994: Diving depths of White-chinned Petrels. Condor 96: 1111-1113.

Imber, M.J. 1973: The food of grey-faced petrels (Pterodroma macroptera gouldi (Hutton)), with special reference to diurnal vertical migration of their prey. Journal of Animal Ecology 42: 645-662.

Imber, M.J. 1976: Breeding biology of the grey-faced petrel Pterodroma macroptera gouldi. Ibis 118: 51-64.

Johnstone, R.M. \& Davis, L.S. 1990: Incubation routines and foraging-trip regulation in the grey-faced petrel Pterodroma macroptera gouldi. Ibis 132: 14-20.

Le Corre, M. 1997: Diving depths of two tropical Pelecaniformes: the red-tailed tropicbird and the red-footed booby. Condor 99(4): 1004-1007.

Lewis, S., Benvenuti, S., Dall'Antonia, L., Griffiths, R., Money, L., Sherratt, T.N., Wanless, S. \& Hamer, K.C. 2002: Sex-specific foraging behaviour in a monomorphic seabird. Proceedings Royal Society London B 269: 1687-1693.

Marchant, S. \& Higgins, P.J. (Co-ordinators) 1990: Handbook of Australian, New Zealand and Antartic birds. Vol. 1: Ratites to Ducks, Part A - Ratites to Petrels. Oxford University Press, Melbourne: $735 \mathrm{PP}$.

Miskelly, C.M. \& Taylor, G.A. 2004: Establishment of a colony of common diving petrels (Pelecanoides urinatrix) by chick transfers and acoustic attraction. Emu 104: 205-211.

Mougin, J.-L. \& Mougin, M.-C. 2000: Maximum diving depths for feeding attained by Bulwer's petrels (Bulweria bulwerii) during the incubation period. Journal of Zoology, London 250: $75-77$.

Oka, N. 1994: Underwater feeding of three shearwaters: Palefooted (Puffinus carneipes), Sooty (P. griseus) and Streaked (Calonectris leucomelas) shearwaters. Journal of Yamashina Institute of Ornithology 26: 8 [-84.

Peck, D.R. \& Congdon, B.C. 2006: Sex-specific chick provisioning and diving behaviour in the wedge-tailed shearwater Puffinus pacificus. Journal of Avian Biology 37: 245-251.

Prince, P.A. \& Jones, M. 1992: Maximum dive depths attained by South Georgia Diving-Petrel Pelecanoides georgicus at Bird Island, South Georgia. Antartic Science 4(4): 433-434.

Prince, P.A., Huin, N. \& Weimerskirch, H. 1994: Diving depths of albatrosses. Antarctic Science 6(3): 353-354.
Robertson, C.J.R., Bell, E. \& Scofield, P. 2004: Autopsy report for seabirds killed and returned from New Zealand fisheries, 1 October 2001 to 30 September 2002: Birds returned by Minisrry of Fisheries observers to the Department of Conservation. DOC SCIENCE INTERNAL SERIES 155. Department of Conservation, Wellington, New Zealand: 43 pp.

Ropert-Coudert, Y., Kato, A., Wilson, R.P. \& Cannell, B.L. 2006: Foraging strategies and prey encounter rate of free-ranging Little Penguins. Marine Biology 149: 139-148.

Sato, K., Naito, Y., Kato, A., Niizuma, Y., Watanuki, Y., Charrassin, J.B., Bost, C.-A., Handrich, Y. \& Le Maho, Y. 2002: Buoyancy and maximal diving depth in penguins: do they control inhaling air volume? Journal of Experimental Biology 205: 1189-1197.

Scolaro, J.A. \& Suburo, A.M. 1991: Maximum diving depths of the Magellanic penguin. Joumal of Field Ornithology 62(2): 204-210.

Shaffer, S.A., Tremblay, Y., Weimerskirch, H., Scott, D., Thompson, D.R., Sagar, P.M., Moller, H., Taylor, G.A., Foley, D.G., Block, B.A. \& Costa, D.P. 2006: Migratory shearwaters integrate oceanic resources across the Pacific Ocean in an endless summer. Proceedings of the National Academy of Sciences 103(34): 12799-12802.

Skira, I. 1979: Underwater feeding by short-tailed shearwaters. Emu 79: 43.

Wanless, S., Burger, A.E. \& Harris, M.P. 1991: Diving depths of shags Phalacrocorax aristoletis breeding on the lsle of May. Ibis 133: 37-42.

Wanless, S., Finney, S.K., Harris, M.P. \& McCafferty, D.J. 1999: Effect of the diel light cycle on the diving behaviour of two bottom feeding marine birds: the Blue-eyed Shag Phalacrocorax atriceps and the European Shag 1? aristotelis. Marine Ecology Progress Series 188: 219-224.

Warham, J. 1990: The Petrels: Their Ecology and Breeding Systems. Academic Press, London: 613 pp.

Watanuki, Y., Wanless, S., Harris, M., Lovvorn, J.R., Miyazaki, M., Tanaka, H. \& Sato, K. 2006: Swim speeds and stroke patterns in wing-propelled divers: a comparison among alcids and a penguin. Journal of Experimental Biology 209: $1217-1230$.

Weimerskirch, H. \& Cherel, Y. 1998: Feeding ecology of shorttailed shearwaters: breeding in Tasmania and foraging in the Antarctic? Marine Ecology Progress Series 167: 261-274.

Weimerskirch, H. \& Sagar, P.M. 1996: Diving depths of sooty shearwaters Puffinus griseus. Ibis 138: 786-794.

West, J. \& Imber, M.J. 1985: Some foods of Hutton's Shearwater (Puffinus huttoni). Notornis 32: 333-336.

Wood, K.A. 1993: Feeding behaviour, offal preferences and tarsus shape of Puffinus shearwaters off central New South Wales. Notornis 40: 123-127.

Zavalaga, C.B. \& Jahncke, J. 1997: Maximum dive depths of the Peruvian diving-petrel. Condor 99: 1002-1004.

(accoted 7 October 2008) 